\title{
HUMAN CAPITAL AND THE FELDSTEIN-HORIOKA PUZZLE
}

\author{
MARGARITA KATSIMI \\ THOMAS MOUTOS
}

CESIFO WORKING PAPER NO. 1914

CATEgORY 5: Fiscal POLICY, MACROECONOMICS AND GROWTH

FEBRUARY 2007

An electronic version of the paper may be downloaded

- from the SSRN website:

- from the RePEc website:

www.SSRN.com

- from the CESifo website:

www.RePEc.org

www.CESifo-group.de 


\title{
HUMAN CAPITAL AND THE FELDSTEIN-HORIOKA PUZZLE
}

\begin{abstract}
In this paper we reexamine the Feldstein-Horioka finding of limited international capital mobility by using a broader view (i.e., including human capital) of investment and saving. We find that the Feldstein-Horioka result is impervious to this change.
\end{abstract}

JEL Code: E2, F2, I2, Q4.

Keywords: human capital, current account, investment-saving correlation, capital mobility.

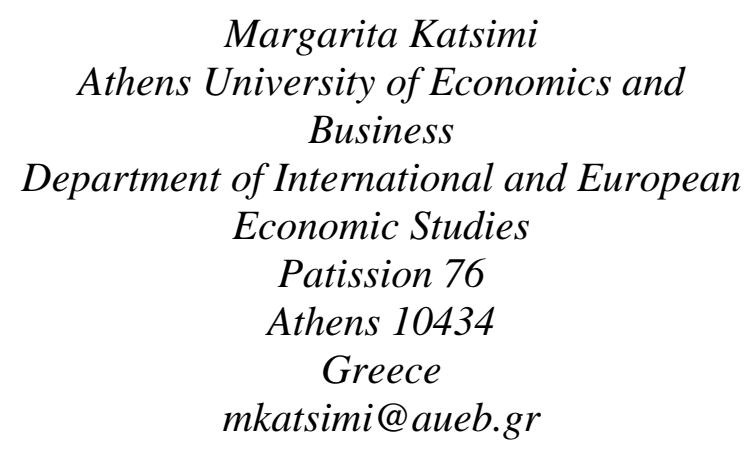

Margarita Katsimi Business Economic Studies

Patission 76

Athens 10434

mkatsimi@aueb.gr

\author{
Thomas Moutos \\ Athens University of Economics and \\ Business \\ Department of International and European \\ Economic Studies \\ Patission 76 \\ Athens 10434 \\ Greece \\ tmoutos@aueb.gr
}

We wish to thank Nikitas Pittis and Sarantis Kalyvitis for many helpful comments and suggestions. 


\section{Introduction}

Models that emphasize the accumulation of human capital as an important determinant of growth have come into prominence during the last two decades (see, for example, Lucas (1988), Azariadis and Drazen (1990), Mankiw, Romer and Weil (1992)). In these models the accumulation of human capital is broadly similar to the accumulation of physical capital since a rise in the accumulation of either type of capital increases the amount of output that can be produced in the future. For example, a household may increase its future consumption opportunities not only by increasing its ownership of (claims to) physical capital, but it can do so by increasing the human capital (and future earning opportunities) of its members. Accordingly, in the same way that an economy in which the marginal productivity of physical capital is higher than the world interest rate may use the opportunity to borrow internationally, an economy in which the marginal productivity of human capital is higher than the world interest rate, may decide to borrow internationally to finance the possible excess of its desired human capital investment over what domestic savings can allow. Consequently, by focusing on the narrower view of capital (i.e., the one excluding human capital) one may bias the results regarding the extent to which domestic savings act as a constraint on domestic investment (broadly interpreted).

In this paper we reexamine the celebrated Feldstein and Horioka (1980) [hereafter $\mathrm{FH}$ ] finding of limited international capital mobility using this broader view of investment (and saving). We find that FH's results are impervious to this change.

\section{Econometric Analysis}

A large strand of the international macroeconomics literature provides strong evidence for a high saving-investment correlation using both time series and cross section techniques. This empirical regularity suggested by $\mathrm{FH}$ has been interpreted as inconsistent with perfect capital mobility, and has as a result triggered a vast response in the literature. In general, one can distinguish among studies that aim at challenging the empirical FH finding [see Sinn (1992) and Caporale et al (2005)] and among those that aim at reconciling this evidence with the existence of full capital mobility [see Bayoumi (1990), Barro et al (1995), Baxter and Crucini (1993) and Coackley et al (1996)].

FH estimate the following cross-section regression for 21 OECD countries:

$$
\left(\frac{I}{Y}\right)_{i}=a+\beta\left(\frac{S}{Y}\right)_{i}+u_{i}
$$

where $I$ denotes gross domestic investment, $S$ denotes gross domestic 
saving , $Y$ denotes gross domestic product and $i$ stands for the individual country. All data are averages of the $1960-1974$ period. FH find that $\beta$ is close to one. The estimate for $\beta$ is 0.89 for the whole period and between (0.87-0.91) for the various 5-year sub-sample periods. This finding has been characterized as a paradox since perfect capital mobility would imply a value of $\beta$ close to zero. Subsequent studies have to a large extent confirmed the $\mathrm{FH}$ paradox.

Our aim is to investigate whether ignoring a commonly neglected but nevertheless important component of investment, namely the investment in human capital has a significant effect on the saving-investment correlation. In order for our results to be comparable to FH's result we first run equation (1) for our sample of 25 OECD countries and then we compare the derived estimates of $\beta$ with those derived if the measure of investment includes investment in human capital. To this purpose we also estimate the following equation:

$$
\left(\frac{I T}{Y}\right)_{i}=a+\beta\left(\frac{\bar{S}}{Y}\right)_{i}+u_{i}
$$

where IT denotes gross domestic investment including investment in human capital, $I h ; I T / Y=I / Y+I h / Y$. We also adjust the total saving ratio by excluding private sector education expenditures from consumption expenditure. Thus, the measure of savings used in equation (1) is augmented by adding to it the private expenditure on education $\left(I h_{p r}\right)$, and so $\bar{S}=S+I h_{p r}$.

As an approximation of investment in human capital, Ih, we use data for total expenditure for education from the OECD Education at a Glance. Ih is defined as total expenditure for education excluding government expenditure designated for augmenting the physical capital used for educational purposes. The reason is the latter expenditures are already included in total investment as part of public investment. Although these data exist for the 1992-2002 period there is very poor coverage before 1997. Specifically, there is no data coverage for 7 out of the 25 countries of our sample prior to 1997 . Ih is divided by GDP from the OECD Economic Outlook. Gross national saving (as \% of GDP), $\frac{S}{Y}$, is also taken by OECD Economic Outlook. Finally, gross capital formation (as \% of GDP), $\frac{I}{Y}$, is from the World Bank, WDI.

Table 1 presents estimates of equation (1) for the 1985-2002 period. 


\begin{tabular}{|c|c|c|c|}
\hline \multicolumn{4}{|c|}{ TABLE 1 : Feldstein-Horioka equation 1} \\
\hline & \multicolumn{3}{|c|}{$\left(\frac{I}{Y}\right)_{i}=a+\beta\left(\frac{S}{Y}\right)_{i}$} \\
\hline method & \multicolumn{3}{|c|}{ Ordinary Least Squares } \\
\hline period & $a$ & $\beta$ & $\operatorname{Adj} . R^{2}$ \\
\hline $86-2002$ & $\begin{array}{l}9.747 \\
(5.047)\end{array}$ & $\begin{array}{l}0.572 \\
(6.767)\end{array}$ & 0.65 \\
\hline $86-90$ & $\begin{array}{l}9.597 \\
(6.313)\end{array}$ & $\begin{array}{c}0.611 \\
(9.446)\end{array}$ & 0.79 \\
\hline $91-95$ & $\begin{array}{l}6.736 \\
(3.637)\end{array}$ & $\begin{array}{l}0.702 \\
(8.344)\end{array}$ & 0.74 \\
\hline $96-2000$ & $\begin{array}{c}14.044 \\
(4.980)\end{array}$ & $\begin{array}{l}0.372 \\
(3.069)\end{array}$ & 0.26 \\
\hline $97-2002$ & $\begin{array}{c}16.441 \\
(5.945\end{array}$ & $\begin{array}{l}0.261 \\
(2.187)\end{array}$ & 0.14 \\
\hline
\end{tabular}

Notes: t-Statistics in parentheses.

Although one can observe a significant decrease in adjusted $R^{2}$ after 1995, $\beta$ coefficients are significant in all sub-samples. Our results are consistent with Sinn (1992) and Taylor (1996) who observe a fall in $\beta$ in the 80's. This fall has apparently become more significant after 1995 and it may well be related to the process of monetary integration among European Union countries which culminated in the adoption of the Euro; see Blanchard and Giavazzi (2002) for more details.

Our next step is to see whether including investment in human capital as a part of total investment will affect the investment-saving correlation. For this purpose, we estimate equation (2) for the 1997-2002 period. This gives us:

$$
\left(\frac{I T}{Y}\right)_{i}=\underset{(8.11)}{21.32}+\underset{(2.55)}{0.277}\left(\frac{\bar{S}}{Y}\right)_{i}
$$

with an adjusted $R^{2}$ of 0.19 . Clearly our results indicate that there is no significant change in the correlation between investment and savings when human capital investment is taken into account. The estimate of $\beta$ is significant and very similar to the one reported in the last raw of Table 1 whereas $\frac{S}{Y}$ seems to explain $19 \%$ of the variation in $\frac{I T}{Y}$.

Some authors, including Feldstein (2005), have suggested that the above results need to re-examined by taking into account the issue of the country size effect: A large country relies less on external borrowing since it is more diversified and national saving may have an impact on world interest rate [see Harberger (1980), Dooley et al (1987) and Sinn (1992)].

An obvious way of testing for a possible size effect is using the ratio of the country's GDP in total GDP as a weight in Weighted Least Squares (WLS). ${ }^{1}$ This is equivalent to running OLS after multiplying all the data

\footnotetext{
${ }^{1}$ Alternatively one can assume that $\beta$ depends on the country size. However,
} 
by the weight series, $w$ so that:

$$
\left(\frac{I}{Y}\right)_{i}^{*}=w_{i} a+\beta\left(\frac{S}{Y}\right)_{i}^{*}+u_{i}^{*}
$$

where $\left(\frac{I}{Y}\right)_{i}^{*}=w_{i}\left(\frac{I}{Y}\right)_{i},\left(\frac{S}{Y}\right)_{i}^{*}=w_{i}\left(\frac{S}{Y}\right)_{i}$ and $u_{i}^{*}=w_{i} u_{i}$.

It is straightforward to show that rejecting model (1) for model (4) improves efficiency if model (1) suffers from heteroskedasticity. Since $\operatorname{Var}\left(u_{i}^{*}\right)=w_{i}^{2} \operatorname{Var}\left(u_{i}\right)$ and $w_{i \neq} w_{j}$, it is clear that if model (1) does not suffer from heteroskedasticity, the use of WLS would introduce heteroskedasticity in our model. The White-heteroskedasticity test of equations (1) and (2) cannot reject homoskedasticity for all periods (apart from the 91-95 period) at the one percent significance level, as reported in the second and third columns of table 2. Furthermore, rerunning equations (1) and (2) using White's heteroskedasticity consistent method results in very similar standard errors apart from the 91-95 period. Still, it is important to test whether equations (1) and (2) suffer from heteroskedasticity of the exact form which can be corrected by the use of $w_{i}$ in WLS. This would be the case if

$$
w_{1}^{2} \operatorname{Var}\left(u_{1}\right)=w_{2}^{2} \operatorname{Var}\left(u_{2}\right)=\ldots=w_{n}^{2} \operatorname{Var}\left(u_{n}\right)
$$

If $w_{i}$ is the right weight in an WLS regression then the squared residuals of equations (1) and (2), $R S Q$, should be correlated with $w_{i}$. Thus, in order to test whether our initial model suffers from heteroskedasticity which can be corrected by the use of $w_{i}$, we run simple OLS regressions of $R S Q$ on $w_{i}$. The results are reported in the last columns of table 2. One can see that in all cases the coefficient on $w_{i}$ is insignificant. This implies that using WLS would introduce heteroskedasticity in our model for the majority of sub-periods, and for this reason we abstain from further examination of this issue. ${ }^{2}$

recursive estimates of $\beta$ suggest that $\beta$ is stable across countries.

${ }^{2}$ Nevertheless, we have chequed whether our results depend on the use of WLS. We found that the inclusion of human capital does not alter the saving-investment correlation even if the latter is estimated by WLS. The results are available upon request. 


\begin{tabular}{|c|c|c|c|c|}
\hline \multicolumn{5}{|c|}{ TABLE 2 : Heteroskedasticity Tests } \\
\hline & \multicolumn{2}{|l|}{ White test } & \multicolumn{2}{|c|}{ Ordinary Least Squares } \\
\hline & \multicolumn{2}{|l|}{ equation (1) } & \multicolumn{2}{|c|}{ Dep var: $R S Q$ of equation (1) } \\
\hline period & F-statistic & Probab. & constant & $w_{i}$ \\
\hline $86-2002$ & 4.4942 & 0.0231 & $\begin{array}{l}4.704 \\
(5.049)\end{array}$ & $\begin{array}{c}-16.288 \\
(-1.531)\end{array}$ \\
\hline $86-90$ & 2.6587 & 0.0935 & $\begin{array}{l}3.176 \\
(3.392)\end{array}$ & $\begin{array}{r}-9.405 \\
(-0.895)\end{array}$ \\
\hline $91-95$ & 7.0659 & 0.0043 & $\begin{array}{l}6.004 \\
(4.239)\end{array}$ & $\begin{array}{c}-21.677 \\
(-1.330)\end{array}$ \\
\hline $96-2000$ & 1.0825 & 0.3561 & $\begin{array}{l}9.712 \\
(4.322)\end{array}$ & $\begin{array}{c}-28.536 \\
(-1.121)\end{array}$ \\
\hline \multirow[t]{3}{*}{$97-2002$} & 0.3060 & 0.7394 & $\begin{array}{c}8.85 \\
(4.015)\end{array}$ & $\begin{array}{l}-21.89 \\
(-0.878)\end{array}$ \\
\hline & \multicolumn{2}{|l|}{ equation (2) } & \multicolumn{2}{|c|}{ Dep var: $R S Q$ of equation (2) } \\
\hline & F-statistic & Probab. & constant & $w_{i}$ \\
\hline $97-2002$ & 1.559 & 0.2326 & $\begin{array}{l}7.578 \\
(4.169)\end{array}$ & $\begin{array}{c}-20.62 \\
(-1.00)\end{array}$ \\
\hline
\end{tabular}

Notes: t-Statistics in parentheses

Concluding, our analysis indicates that the traditional saving-investment correlation does not alter significantly once we broaden the measure of investment and saving by taking human capital into account. Moreover, our analysis confirms the widespread belief, and the finding of previous studies, that the degree of international capital mobility has increased significantly since the mid-seventies.

\section{References}

[1] Azariadis, B. and A. Drazen, 1990, Threshold Externalities in Economic Development, Quarterly Journal of Economics 105, 501-526.

[2] Bayoumi ,T., 1990, Saving-Investment Correlations: Immobile Capital, Government Policy or Endogenous Behavior?, IMF Staff Papers, vol. 37, 360-387.

[3] Barro, R. J., Mankiw, N. G. and X. Sala-i-Martin, 1995, Capital Mobility in Neoclassical Models of Growth, American Economic Review 85, 103-115.

[4] Baxter, M. and M. J. Crucini, 1993, Explaining Saving-Investment Correlations, American Economic Review 83, 416-436.

[5] Blanchard, O. and F. Giavazzi, 2002, Current Acount Deficits in the Euro Area. The End of the Feldstein-Horioka Puzzle?, MIT Economics Department Working Paper 03-05.

[6] Caporale, M. G., Panopoulou, E. and N. Pittis, 2005, The FeldsteinHorioka puzzle revisited: A Monte Carlo study, Journal of International Money and Finance 24, 1143-1149.

[7] Coackley, J., Kulasi, F. and R. Smith, 1996, Current Account Sol- 
vency and the Feldstein-Horioka Puzzle, Economic Journal 106, 620627.

[8] Dooley, M., Frankel, J. and Mathieson D, 1987, International Capital Mobility: What Do Saving-Investment Correlations Tell Us?, IMF Staff Papers vol 34, 503-530.

[9] Feldstein, M., 2005, Monetary Policy in a Changing Economic Environment: The Role of Global Capital Flows, NBER Working Paper 11856.

[10] Feldstein, M. and C. Horioka, 1980, Domestic Saving and International Capital Flows, Economic Journal 90, 314-329.

[11] Harberger A. C., 1980, Vignettes on the World Capital Markets, American Economic Review 70, Papers and Proceedings, 331-337.

[12] Lucas, R., 1988, On the Mechanics of Economic Growth, Journal of Monetary Economics 22, 3-42.

[13] Mankiw, N. G., Romer, D. and D. N. Weil, 1992, A Contribution to the Empirics of Economic Growth, Quarterly Journal of Economics 107, 407-437.

[14] Sinn, S., 1992, Saving-Investment Correlations and Capital Mobility: On the Evidence from Annual Data, Economic Journal 102, 1162-1170.

[15] Taylor A. M., 1996, International Capital Mobility in History: The Saving-Investment Relationship, NBER Working Paper 5743. 


\section{CESifo Working Paper Series}

(for full list see www.cesifo-group.de)

1852 Luca Anderlini, Leonardo Felli and Andrew Postlewaite, Active Courts and Menu Contracts, November 2006

1853 Andreas Haufler, Alexander Klemm and Guttorm Schjelderup, Economic Integration and Redistributive Taxation: A Simple Model with Ambiguous Results, November 2006

1854 S. Brock Blomberg, Thomas DeLeire and Gregory D. Hess, The (After) Life-Cycle Theory of Religious Contributions, November 2006

1855 Albert Solé-Ollé and Pilar Sorribas-Navarro, The Effects of Partisan Alignment on the Allocation of Intergovernmental Transfers. Differences-in-Differences Estimates for Spain, November 2006

1856 Biswa N. Bhattacharyay, Understanding the Latest Wave and Future Shape of Regional Trade and Cooperation Agreements in Asia, November 2006

1857 Matz Dahlberg, Eva Mörk, Jørn Rattsø and Hanna Ågren, Using a Discontinuous Grant to Identify the Effect of Grants on Local Taxes and Spending, November 2006

1858 Ernesto Crivelli and Klaas Staal, Size and Soft Budget Constraints, November 2006

1859 Jens Brøchner, Jesper Jensen, Patrik Svensson and Peter Birch Sørensen, The Dilemmas of Tax Coordination in the Enlarged European Union, November 2006

1860 Marcel Gérard, Reforming the Taxation of Multijurisdictional Enterprises in Europe, "Coopetition" in a Bottom-up Federation, November 2006

1861 Frank Blasch and Alfons J. Weichenrieder, When Taxation Changes the Course of the Year - Fiscal Year Adjustments and the German Tax Reform 2000/2001, November 2006

1862 Hans Jarle Kind, Tore Nilssen and Lars Sørgard, Competition for Viewers and Advertisers in a TV Oligopoly, November 2006

1863 Bart Cockx, Stéphane Robin and Christian Goebel, Income Support Policies for PartTime Workers: A Stepping-Stone to Regular Jobs? An Application to Young LongTerm Unemployed Women in Belgium, December 2006

1864 Sascha O. Becker and Marc-Andreas Muendler, The Effect of FDI on Job Separation, December 2006

1865 Christos Kotsogiannis and Robert Schwager, Fiscal Equalization and Yardstick Competition, December 2006 
1866 Mikael Carlsson, Stefan Eriksson and Nils Gottfries, Testing Theories of Job Creation: Does Supply Create Its Own Demand?, December 2006

1867 Jacques H. Drèze, Charles Figuières and Jean Hindriks, Voluntary Matching Grants Can Forestall Social Dumping, December 2006

1868 Thomas Eichner and Marco Runkel, Corporate Income Taxation of Multinationals and Unemployment, December 2006

1869 Balázs Égert, Central Bank Interventions, Communication and Interest Rate Policy in Emerging European Economies, December 2006

1870 John Geweke, Joel Horowitz and M. Hashem Pesaran, Econometrics: A Bird's Eye View, December 2006

1871 Hans Jarle Kind, Marko Koethenbuerger and Guttorm Schjelderup, Taxation in TwoSided Markets, December 2006

1872 Hans Gersbach and Bernhard Pachl, Cake Division by Majority Decision, December 2006

1873 Gunther Schnabl, The Evolution of the East Asian Currency Baskets - Still Undisclosed and Changing, December 2006

1874 Horst Raff and Michael J. Ryan, Firm-Specific Characteristics and the Timing of Foreign Direct Investment Projects, December 2006

1875 Jukka Pirttilä and Håkan Selin, How Successful is the Dual Income Tax? Evidence from the Finnish Tax Reform of 1993, December 2006

1876 Agnieszka Stążka, Sources of Real Exchange Rate Fluctuations in Central and Eastern Europe - Temporary or Permanent?, December 2006

1877 Xavier Calsamiglia, Teresa Garcia-Milà and Therese J. McGuire, Why do Differences in the Degree of Fiscal Decentralization Endure?, December 2006

1878 Natacha Gilson, How to be Well Shod to Absorb Shocks? Shock Synchronization and Joining the Euro Zone, December 2006

1879 Scott Alan Carson, Modern Health Standards for Peoples of the Past: Biological Conditions by Race in the American South, 1873 - 1919, December 2006

1880 Peter Huber, Michael Pfaffermayr and Yvonne Wolfmayr, Are there Border Effects in the EU Wage Function?, December 2006

1881 Harry Flam and Håkan Nordström, Euro Effects on the Intensive and Extensive Margins of Trade, December 2006

1882 Panu Poutvaara and Mikael Priks, Hooliganism in the Shadow of the 9/11 Terrorist Attack and the Tsunami: Do Police Reduce Group Violence?, December 2006 
1883 Ruud A. de Mooij and Gaëtan Nicodème, Corporate Tax Policy, Entrepreneurship and Incorporation in the EU, December 2006

1884 Johannes Becker and Clemens Fuest, Corporate Tax Policy and International Mergers and Acquisitions - Is the Tax Exemption System Superior?, January 2007

1885 Momi Dahan and Udi Nisan, The Effect of Benefits Level on Take-up Rates: Evidence from a Natural Experiment, January 2007

1886 José García-Solanes, Francisco I. Sancho-Portero and Fernando Torrejón-Flores, Beyond the Salassa-Samuelson Effect in some New Member States of the European Union, January 2007

1887 Peter Egger, Wolfgang Eggert and Hannes Winner, Saving Taxes Through Foreign Plant Ownership, January 2007

1888 Timothy J. Goodspeed and Andrew Haughwout, On the Optimal Design of Disaster Insurance in a Federation, January 2007

1889 Wim Groot, Henriëtte Maassen van den Brink and Bernard van Praag, The Compensating Income Variation of Social Capital, January 2007

1890 Bas Jacobs, Ruud A. de Mooij and Kees Folmer, Analyzing a Flat Income Tax in the Netherlands, January 2007

1891 Hans Jarle Kind, Guttorm Schjelderup and Frank Stähler, Newspapers and Advertising: The Effects of Ad-Valorem Taxation under Duopoly, January 2007

1892 Erkki Koskela and Rune Stenbacka, Equilibrium Unemployment with Outsourcing under Labour Market Imperfections, January 2007

1893 Maarten Bosker, Steven Brakman, Harry Garretsen, Herman de Jong and Marc Schramm, The Development of Cities in Italy 1300 - 1861, January 2007

1894 Michel Beine, Oscar Bernal, Jean-Yves Gnabo and Christelle Lecourt, Intervention Policy of the BoJ: A Unified Approach, January 2007

1895 Robert S. Chirinko and Daniel J. Wilson, State Investment Tax Incentives: A Zero-Sum Game?, January 2007

1896 Theo S. Eicher and Oliver Roehn, Sources of the German Productivity Demise Tracing the Effects of Industry-Level ICT Investment, January 2007

1897 Helge Berger, Volker Nitsch and Tonny Lybek, Central Bank Boards around the World: Why does Membership Size Differ?, January 2007

1898 Gabriel Felbermayr and Wilhelm Kohler, Does WTO Membership Make a Difference at the Extensive Margin of World Trade?, January 2007 
1899 Benno Torgler and Friedrich Schneider, The Impact of Tax Morale and Institutional Quality on the Shadow Economy, January 2007

1900 Tomer Blumkin and Efraim Sadka, On the Desirability of Taxing Charitable Contributions, January 2007

1901 Frederick van der Ploeg and Reinhilde Veugelers, Higher Education Reform and the Renewed Lisbon Strategy: Role of Member States and the European Commission, January 2007

1902 John Lewis, Hitting and Hoping? Meeting the Exchange Rate and Inflation Criteria during a Period of Nominal Convergence, January 2007

1903 Torben M. Andersen, The Scandinavian Model - Prospects and Challenges, January 2007

1904 Stephane Dees, Sean Holly, M. Hashem Pesaran and L. Vanessa Smith, Long Run Macroeconomic Relations in the Global Economy, January 2007

1905 Richard Jong-A-Pin and Jakob De Haan, Political Regime Change, Economic Reform and Growth Accelerations, January 2007

1906 Sascha O. Becker and Peter H. Egger, Endogenous Product versus Process Innovation and a Firm's Propensity to Export, February 2007

1907 Theo S. Eicher, Chris Papageorgiou and Oliver Roehn, Unraveling the Fortunates of the Fortunate: An Iterative Bayesian Model Averaging (IBMA) Approach, February 2007

1908 Liliana E. Pezzin, Robert A. Pollak and Barbara S. Schone, Efficiency in Family Bargaining: Living Arrangements and Caregiving Decisions of Adult Children and Disabled Elderly Parents, February 2007

1909 Christian Keuschnigg and Soren Bo Nielsen, Self-Selection and Advice in Venture Capital Finance, February 2007

1910 Rune Jansen Hagen and Gaute Torsvik, Irreversible Investments, Dynamic Inconsistency and Policy Convergence, February 2007

1911 Eric A. Hanushek and Ludger Woessmann, The Role of School Improvement in Economic Development, February 2007

1912 Bernard M. S. van Praag, Perspectives from the Happiness Literature and the Role of New Instruments for Policy Analysis, February 2007

1913 Volker Grossmann and Thomas M. Steger, Growth, Development, and Technological Change, February 2007

1914 Margarita Katsimi and Thomas Moutos, Human Capital and the Feldstein-Horioka Puzzle, February 2007 